\title{
Stillbirth Indicator
}

National Cancer Institute

\section{Source}

National Cancer Institute. Stillbirth Indicator. NCI Thesaurus. Code C122194.

Specifies whether any pregnancies resulted in stillbirths. 